\title{
O DIA EM QUE ME TORNEI LIVRE
}

Numa cinzenta manhã de março

Reconheci que sou mais fraco do que meus desejos

E passei a levá-los a sério

Com o respeito e o medo dignos de um inimigo

Todo deleite que outrora me traziam

Tornou-se infantil e previsível - diria, banal

E no fértil terreno de minhas expectativas

Sobrou um deserto de realidade.

Quando, então, germinou algo que estava enterrado

A semente da liberdade

Que cresceu com o ar de minhas longas respirações

Impulsionada pelas fortes batidas do meu coração

Foi a primeira vez que me vi!

Flertei com meus antigos demônios

Blasfemei todos os encantos ao redor

Dominei, afinal, minha solidão

E um arco-íris de paz se abriu

No horizonte de minh'alma.

Francisco Soares Reis Júnior Mestrando em Ciência Política/UFPI 